використання принципів логістики у взаємозв'язках між елементами виробничого потенціалу.

Логістика за своєю сутністю в процесі управління господарською діяльністю виконує інтеграційні функції. Тому до іiі основних завдань відносять:

- створення комплексних інтегрованих систем матеріальних, інформаційних та інших потоків;

- стратегічне узгодження, планування i контроль за використанням логістичних потужностей сфер виробництва й обігу;

- постійне вдосконалювання логістичної концепції в рамках обраної стратегії в ринковому середовищі;

- досягнення високої системної гнучкості шляхом швидкого реагування на зміни зовнішніх $\mathrm{i}$ внутрішніх умов функціонування.

Серед основних складових забезпечення економічного ефекту, від використання логістики в сфері управління виробничим потенціалом підприємства є:

- зменшення запасів на всьому шляху руху матеріального потоку;

- скорочення часу проходження товарів по логістичному ланцюгу;

- забезпечення ефективності використання основних фондів та обігових засобів;

- зменшення витрат ручної праці i, відповідно, витрат на операції з вантажем та ін.

Висновки. Виробничий потенціал підприємства є складною і динамічною системою. Взаємозв'язки між окремими складовими потенціалу здійснюють безпосередній вплив на його елементи, модифікуючи вихідні властивості i закономірності їх функціонування, сприяючи тим самим переходу потенціалу у новий якісний стан. Тобто від якості взаємозв'язків між елементами виробничого потенціалу підприємства залізничного транспорту залежить ефективність його використання. Забезпечити дійове управління потоковими процесами між елементами виробничого потенціалу можна за рахунок використання принципів логістики.

\section{СПИСОК ЛІТЕРАТУРИ}

1 Галушко Д.В. Управление конкурентным потенциалом предприятия железнодорожного машиностроения на основе реализации принципов наступательной стратегии : дис. канд. эконом. наук : 08.00.05 / Д.В. Галушко. - Брянск, 2007. - 142 с.

2 Добикіна О.К. Потенціал підприємства: формування та оцінка : навч. посіб. / О.К. Добикіна та ін. - К.: Центр навчальної літератури, 2007. - 202 c.

3 Должанський І.3. Управління потенціалом підприємства : навч. посіб. / І.З. Должанський та ін. - К.: Центр навчальної літератури, 2006. - 362 с.

4 Іщук С. Концептуальні засади формування та розвитку виробничого потенціалу промислових підприємств / С. Іщук // Регіональна економіка. - 2005. - № 3. - с. 48-56.

5 Федонін О.С. Потенціал підприємства: формування та оцінка : навч. посіб. / О.С. Федонін. - К.: КНЕУ, 2004. - 316 c.

6 Бараш Ю.С. Управління залізничним транспортом країни: 2-е вид., перероб. і доп / Ю.С. Бараш. - Дніпропетровськ, 2006. - 259 с.

7 Дикань В.Л. Механізм створення залізнично-транспортно-промислової групи в сучасних умовах розвитку залізничного транспорту України / В.Л. Дикань, М.В. Кондратюк // Вісник економіки транспорту і промисловості. - 2009. - № 26. - C. 13-18.

Рецензент д.е.н., професор УкрДАЗТ Кірдіна О.Г. Експерт редакційної колегії к.е.н., доцент УкрДАЗТ Токмакова І.В.

УДК 656.07.001.76

\title{
УДОСКОНАЛЕННЯ ІННОВАЦІЙНОЇ ІНФРАСТРУКТУРИ ПІДПРИЕМСТВ ЗАЛІЗНИЧНОГО ТРАНСПОРТУ
}

\author{
Зубенко В.О., к.е.н, доцент,
} Чернавіна І.О., магістр (УкрДАЗТ)

В статті виконано аналіз проблем, пов'язаних з прискоренням інноваційного розвитку підприємств залізничного транспорту. Доведена необхідність інтеграції науки і логістики, а також гострої необхідності наявності добре сформованої інноваџійної інфраструктури підприємств залізничного транспорту. 
В якості базової складової удосконаленої інноваційної інфраструктури запропонована інформаційно-логістична складова, яка повинна стати базисом інноваційної діяльності, тобто проходити через всі етапи інноваційного процесу з метою їх системної оптимізації, а також фінансових, інформаційних, матеріальних та інших потоків, пов'язаних із здійсненням інноваційної діяльності в галузі, для досягнення поставлених иілей.

Ключові слова: інновація, інноваційна діяльність, залізничний транспорт, інфраструктура, інноваційна інфраструктура.

\title{
УСОВЕРШЕНСТВОВАНИЕ ИННОВАЦИОННОЙ ИНФРАСТРУКТУРЫ ПРЕДПРИЯТИЙ ЖЕЛЕЗНОДОРОЖНОГО ТРАНСПОРТА
}

\author{
Зубенко В.А., к.э.н, доцент, \\ Чернавина И.А., магистр (УкрГАЖТ)
}

В статье выполнен анализ проблем, связанных с ускорением инновационного развития железнодорожного транспорта. Доказана необходимость интеграции науки и логистики, а также острой необходимости наличия хорошо сформированной инновационной инфраструктуры предприятий железнодорожного транспорта.

В качестве базовой составляющей усовершенствования инновачионной инфраструктурь предложена информаџионно-логистическая составляющая, которая должна стать базисом инновационной деятельности, то есть проходить через все этапь инновационного процесса с ичелью их системной оптимизации, а также финансовых, информационных, материальньхх и прочих потоков, связанных с осуществлением инновационной деятельности в отрасли, для достижения поставленньх изелей.

Ключевые слова: инновация, инновационная деятельность, железнодорожный транспорт, инфраструктура, инновационная инфраструктура.

\section{INNOVATION INFRASTRUCTURE IMPROVEMENT OF RAILWAY TRANSPORT}

\author{
Zubenko V. A., candidate of economics, \\ Chernavina I.A., master (USA of RT)
}

The analysis of problems, related to the acceleration of innovative development of railway transport is executed in the article. The necessity of integration of science and logistic is well-proven, and also to the sharp necessity of presence of the well-shaped innovative infrastructure of enterprises of railway transport.

As a base constituent of improvement of innovative infrastructure an informative-logistic constituent which must become the base of innovative activity is offered, that to pass through all stages of innovative process with the purpose of their system optimization, and also financial, informative, financial and other streams, related to realization of innovative activity in industry, for achievement of the put aims.

For providing of efficiency of innovative activity it is suggested to plug an informative-logistic block in making infrastructural providing of innovative activity of enterprises of railway transport.

Keywords: innovation, innovative activity, railway transport, infrastructure, innovative infrastructure.

Простановка проблеми. Розвиток залізничного транспорту направлений на забезпечення потреб в перевезеннях вантажів та пасажирів при дотриманні високих стандартів якості в обслуговуванні споживачів.

Це можливо на основі ефективного функціонування i модернізації залізничного транспорту, постійного оновлення техніки, впровадження сучасних технологій обслуговування ремонту рухомого складу, передавальних пристроїв та інфраструктури, вдосконалення процесів організації праці $\mathrm{i}$ управління на залізничному транспорті.
Глибока системна криза, яку переживає економіка України, нестабільність управлінських структур, часта зміна кадрів, недостатне фінансування передбачених законодавством заходів негативно позначилися на змісті, послідовності та результативності реалізації заходів інноваційної політики в галузі.

В сучасних умовах господарювання науково-технічний прогрес спроможний стати стрижнем поступового економічного зростання залізничного транспорту основою якого $\epsilon$ інноваційна діяльність, що здатна перетворитися на вирішальний фактор соціально-економічного 
розвитку і відіграти провідну роль у вирішенні головних завдань.

Однак, забезпечити ефективність інноваційної діяльності підприємств залізничного транспорту в умовах нестабільного зовнішнього середовища та загострення конкурентної боротьби на внутрішньому та зовнішньому ринках транспортних перевезень, можливо лише за рахунок формування дієвої інноваційної інфраструктури.

Аналіз досліджень та публікацій. На сьогодні тема дослідження інноваційної діяльності досить популярна, їй присвячена ціла низка праць за авторством: Б.Твісса, Б.Санто, Н. Каленська, Д.Чистилін, І. Шовкун та ін. [1-5].

Проблемами економіки залізничного транспорту та визначення умов та шляхів забезпечення ефективності інноваційної діяльності підприємств галузі займались такі вчені, як В.Дикань, Ю.Кулаєв, В.Пасічник, Є.Сич та багато інших [6-9].

Аналіз теоретичних напрацювань із зазначеної проблематики свідчить про високу зацікавленість вітчизняних та закордонних вчених. Разом з тим явно необхідні нові дієві пропозиції, що дозволять добитися високих економічних результатів в проблемі формування дієвої інноваційної інфраструктури підприємств залізничного транспорту.

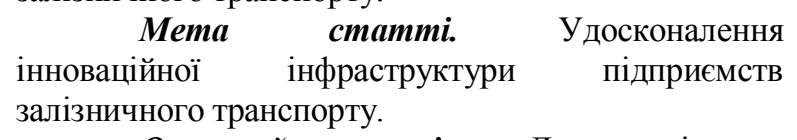

Основний матеріал. Для вирішення поставленого завдання, а саме формування дієвої структури інноваційної діяльності, спочатку розглянемо особливості інноваційної діяльності підприємств залізничного транспорту.

Існує ряд чинників, що відзначають особливу роль інноваційної діяльності для ефективної роботи залізничного транспорту.

По-перше, висока фондомісткість залізничного транспорту i значний ступінь морального і фізичного зносу матеріально-технічної бази визначає масштаби інноваційного оновлення основних виробничих фондів галузі.

По-друге, скорочення можливості підтримки технічного рівня основних фондів за рахунок капітального ремонту, оскільки більшість ремонтних підприємств має морально і фізично застарілий парк устаткування i технологічне оснащення, орієнтоване на підтримку ресурсу технічних засобів, тоді як ситуація, що склалась наразі, вимагає наявності сучасних інноваційних технологій по відновленню і продовженню ресурсу техніки.

По-третє, недостатня інвестиційна активність, фінансування якої за рахунок власних джерел галузі практично вичерпано, а масштаби залучення позикових засобів незначні, що посилює значення інноваційної складової в реалізації інвестиційних заходів.

Наступним фактором $€$ рівень інформатизації на залізничному транспорті, при якому інформаційні технології використовуються не тільки безпосередньо для управління перевізним процесом і функціонування інфраструктури, але й в управлінні маркетингом, економікою і фінансами, а також в соціальній сфері, що вимагає високих темпів технічного і програмного переоснащення інформаційних процесів, що обумовлює необхідність постійного інноваційного супроводу.

I, нарешті, значна матеріаломісткість i енергоємність залізничного виробництва визначають актуальність інноваційних заходів, направлених на ресурсозбереження.

Сучасний етап інноваційного розвитку залізничного транспорту не є досконалим.

До основних чинників, які гальмують інноваційні процеси в залізничній галузі України прийнято відносити:

- відсутність достатніх джерел фінансування;

- високий рівень конкуренції на внутрішньому та міжнародному ринках транспортних перевезень; інновацій;

- недосконалість законодавчої бази у сфері

- міграція висококваліфікованих фахівців до високо розвинутих країн; технологічної бази; відсутність інформаційної та

- відсутність необхідного супроводу інноваційної діяльності та ін.

Зазначені проблеми є суттєвими, однак головна причина безрезультатності інноваційної діяльності залізничного транспорту України криється не в інноваційних ідеях (інноваційні ідеї для підприємств галузі розробляє велика кількість ПКБ, НДІ та вищих навчальних закладів) та фінансових ресурсах (хоча їх рівень недостатній, проте фінансування інноваційної діяльності відбувається регулярно). Головною проблемою на сучасному етапі $\epsilon$ визначення всіх необхідних елементів системи інфраструктурного забезпечення інноваційної діяльності підприємств залізничного транспорту, спроможного підвищити рівень реалізованості та ефективності інноваційної діяльності.

Інфраструктура (лат. infra - під, structura структура) являє собою комплекс виробничих i невиробничих галузей, що забезпечують нормальні умови відтворення (зв'язок, транспорт, освіта, охорона здоров'я та ін.).

Інноваційна інфраструктура - це безліч суб'єктів інноваційної діяльності, які виконують функції обслуговування та сприяння інноваційним процесам [3]. 
За допомогою різних елементів інноваційної інфраструктури вирішуються такі основні завдання сприяння інноваційній діяльності, як:

1) інформаційне забезпечення;

2) виробничо-технологічна підтримка інноваційної діяльності;

3) завдання сертифікації та стандартизації інноваційної продукції;

4) сприяння просуванню ефективних розробок та реалізації інноваційних проектів;

5) проведення виставок інноваційних проектів і продуктів;

6) надання консультаційної допомоги;

7) підготовка, перепідготовка та підвищення кваліфікації кадрів для інноваційної діяльності та інші.

В економічній літературі до складу інфраструктурного забезпечення відносять [3-5] : фінансову інфраструктуру: кредитнофінансові заклади, венчурні фонди, фонди держпідтримки інноваційної діяльності та ін.; консалтингову інфраструктуру: консалтингові та інжинірингові агентства, центри стандартизації, метрології та сертифікації;

- правову інфраструктуру: юридичні консультації, законодавчі органи та ін.;

- маркетингову інфраструктуру: рекламні агентства, маркетингові центри, ярмарки, виставки;

кадрову інфраструктуру: ВН3, коучінг-центри, центри перепідготовки та підвищення кваліфікації; виробничо-технічну інфраструктуру: НДІ, бізнес-інкубатори, наукові парки, технопарки, технополіси, інноваційно-технологічні центри, центри трансферу технологій та ін.;

- інформаційну інфраструктуру.

Однак, на наш погляд, цього не достатньо для забезпечення ефективності інноваційної діяльності підприємств залізничного транспорту, обов'язково при створенні інфраструктури інноваційної діяльності необхідно врахувати той факт, що успіх може бути досягнуто лише на базі системної оптимізації комплексу процесів, пов'язаних із забезпеченням ефективності інноваційної діяльності, а також виробництвом та збутом ii результатів, тобто на основі сучасних логістичних процесів організації руху матеріальних, інформаційних та фінансових потоків, що створюються в результаті інноваційної діяльності залізничного транспорту.

До числа суб'єктивних факторів, що впливають на інноваційну діяльність вітчизняних підприємств залізничного транспорту i обумовлюють необхідність застосування принципів логістичного управління ними, слід віднести:
- досить високий ступінь монополізації залізничного транспорту;

- яскраво виражену спеціалізацію окремих підприємств залізничного транспорту, що не завжди відповідає вимогам ринку;

- необхідність підвищення інвестиційної привабливості залізничного транспорту;

- необхідність інтегрування виробничих процесів всередині підприємств залізничного транспорту;

- наявність специфіки в основній діяльності залізничного транспорту;

- необхідність організації сервісного обслуговування споживачів продукції залізничного транспорту та ін.

Саме тому, вважаємо за доцільне до складових інфраструктурного забезпечення інноваційної діяльності підприємств залізничного транспорту включити інформаційно-логістичний блок, головна задача якого полягає в системній оптимізації комплексу процесів, пов'язаних із забезпеченням ефективності інноваційної діяльності, а також виробництвом та збутом іiі результатів.

Інформаційно-логістична складова повинна бути базисом інноваційної діяльності, тобто проходити через всі етапи інноваційного процесу 3 метою їх системної оптимізації, а також фінансових, інформаційних, матеріальних та інших потоків, пов'язаних із здійсненням інноваційної діяльності в галузі, для досягнення поставлених цілей.

Кожна 3 визначених складових системи інфраструктурного забезпечення інноваційної діяльності залізничного транспорту (фінанси, експлуатаційно-технологічна складова, консалтингова складова, кадрова складова, маркетингова складова, правова складова та інформаційно-логістична складова) має бути покладена на підприємства галузі та відповідні служби залізниць, спроможних виконувати покладені на них обов'язки та функції в повному обсязі та у встановлений термін.

Висновки. В сучасних умовах економічний розвиток залізничного транспорту неможливо уявити без інноваційного розвитку підприємств галузі.

\section{є досконалим.}

Сучасний етап їх інноваційного розвитку не

Аналіз проблем, пов'язаних з прискоренням інноваційного розвитку підприємств залізничного транспорту та держави, свідчить про актуальність інтеграції науки, логістики, а також про гостру необхідність наявності добре сформованої інфраструктури підтримки всіх видів зв'язків між підприємствами залізничного транспорту та науковими організаціями, що є провідними в галузі інноваційного розвитку. 
В якості базової складової інноваційної інфраструктури запропонована інформаційнологістична складова, яка повинна стати базисом інноваційної діяльності, тобто проходити через всі етапи інноваційного процесу з метою їх системної оптимізації, а також фінансових, інформаційних, матеріальних та інших потоків, пов'язаних із здійсненням інноваційної діяльності в галузі, для досягнення поставлених цілей.

Для забезпечення ефективності інноваційної діяльності запропоновано включити інформаційно-логістичний блок до складових інфраструктурного забезпечення інноваційної діяльності підприємств залізничного транспорту. Даний блок повинний стати базовим.

\section{СПИСОК ЛІТЕРАТУРИ}

1. Санто Б. Инновация как средство экономического развития / Общ. Ред. и вступл. Б.В. Сазонова. - М.: Прогресс, 1990. - 296 с.

2. Твисс Б. Управление научно-техническими нововведениями. / Б.Твисс - М.:Экономика, 1989. $217 \mathrm{c}$

3. Каленская Н.В .Инфраструктурное обеспечение инновационной деятельности / Н. В.
Каленская // Российское предпринимательство. 2007. - № 7 Вып. 2(94). - С. 55-58.

4. Чистилин Д. К вопросу стратегии экономического роста Украины / Д. Чистилин // Экономика Украины. - 2003. - № 1. - С. $52-59$.

5. Шовкун I. А. Інстутаційні передумови формування інноваційної спрямованості економічного розвитку України / I. А. Шовкун // Наук. пр. Донец. нац. техн. ун-ту. Серія економічна. - Донецьк, 2004. - Вип. 69. - С. 191 - 198.

6. Дикань В.Л. Забезпечення ефективності інноваційної діяльності підприємств залізничного транспорту: Монографія / В.Л. Дикань, В.О. Зубенко. - Харків: УкрДАЗТ, 2008. - 194 с.

7. Кулаєв Ю.Ф. Концептуальные аспекты оптимального управления пассажирскими перевозками / Ю.Ф.Кулаєв, И.М.Аксенов // Залізничний транспорт України. - 2000. - №4. - С.28.

8. Пасічник B.I. Управління економікою експлуатаційної роботи залізниць України: навч. пос. / В.І.Пасічник. - К.: Основа, 2005. - 376 с.

9. Сич Є.М. Теоретичні основи розвитку інноваційно-інвестиційних систем / Є.М.Сич, В.П.Ільчук // Проблеми і перспективи розвитку банківської системи України. - 2003.- Т.8. - С. 64-68.

УдК658.7

\title{
ОСОБЕН НОСТИ ОРГАНИЗАЦИИ РАБОТЫ СКЛАДСКИХ КОМПЛЕКСОВ В ЛОГИСТИЧЕСКИХ СИСТЕМАХ В СОВРЕМЕННЫХ УСЛОВИЯХ
}

\author{
Каличева Н.Е., к.э.н, доцент, \\ Рустамова Л.Г., магистр (УкрДАЗТ)
}

\begin{abstract}
В статье рассмотрено место и роль складских комплексов в современных логистических системах. Предложены пути оптимальной организации работы складских комплексов, а именно пикинга, для оптимизации затрат логистичной системы. Определено, что организовывать работу склада должен профессионал, так как такой руководитель сможет оперативно устранить недочеть и «подтянуть» слабые места в функиионировании складских комплексов.
\end{abstract}

Ключевые слова: организация складского хозяйства, складская логистика, логистические системы, пикинг, персонал.

\section{ОСОБЛИВОСТІ ОРГАНІЗАЦЇ̈ РОБОТИ СКЛАДСЬКИХ КОМПЛЕКСІВ В ЛОГІСТИЧНИХ СИСТЕМАХ СУЧАСНИХ УМОВАХ}

\author{
Каличева Н.С., к.е.н., доцент, \\ Рустамова Л.Г., махістр (УкрДАЗТ)
}

У статті розглянуто місие і роль складських комплексів в сучасних логістичних системах. Запропоновано иляхи оптимальної організації роботи складських комплексів, а саме пікінг, для 